\title{
Quotations and quotatives
}

\section{Spronck, Stef}

Brill

2022

Spronck, S 2022 , Quotations and quotatives . in M L Greenberg , L A Grenoble , S M pÿDickey , R Genis, M AaziDski, M Oslon, A Peti-Stanti, M Ueda Fidler, M Uhlik, B Wiemer \& N V Zorixina-Nilsson (eds), Encyclopedia of Slavic Language and Linguistics . Brill , Leiden . https://doi.org/10.1163/2589-6229_eslo_com_032182

http://hdl.handle.net/10138/340893

https://doi.org/10.1163/2589-6229_eslo_com_032182

unspecified

acceptedVersion

Downloaded from Helda, University of Helsinki institutional repository.

This is an electronic reprint of the original article.

This reprint may differ from the original in pagination and typographic detail.

Please cite the original version. 


\section{Quotation and quotatives}

\section{Abstract}

This chapter introduces quotation (more precisely, direct and indirect speech) and quotatives in Slavic. The second category is defined here as a variety of strategies presenting a reported message as an utterance spoken or thought at a moment other than the current moment of speech, but formulated in the here-and-now by the current speaker and often signalled through particles. The chapter discusses several different approaches to these phenomena and illustrates them using corpus examples. It concludes with three complications in the classification and analysis of quotation and quotatives.

\section{Introduction}

Talking about utterances from previous conversations is the linguistic fabric of culture. Most of what we know we have been told, and all known languages have dedicated constructions to express that what we say reflects the words and thoughts of others.

Vološinov (1930) proposed that these constructions present a unique opportunity to study how language form is shaped by social interaction. In expressions of čužaja reč' 'other speech', after the English translation of the volume (Vološinov 1973) often referred to as 'reported speech', the way in which the voices and expectations of others constitute our social world is made visible in language structure. Examples include the expressions in (1-4). (Please note that for the purpose of consistency transliterations and glosses of all examples cited below may have been modified from their original sources.)

(1) $\mathrm{Ru}$

Иван сказал: <<Я приеду завтра $>>$

Ivan skazal:

"Јa priedu

zavtra."

Ivan say.IPFV.PST $1 \mathrm{SG}$ arrive.PFV tomorrow

'Ivan said: "I shall arrive tomorrow."' (Barentsen 1996: 16)

(2) Po

Podobnoś już

Allegedly already in

brany

taken.msg by

father.ACC w powijakach byłem

infancy.LOC be.PST.M.SG

ojca

na konia

'It is said that already in my infancy I was taken on horseback rides by my father (Wiemer 2005: 125)

(3) $\mathrm{Bg}$ Стефан заминал за Бургас

$\begin{array}{llll}\text { Stefan } & \text { zaminal } & \text { za } & \text { Burgas } \\ \text { Stefan } & \text { leave.PST.PTCP } & \text { for } & \text { Burgas }\end{array}$


8)

(4) $\mathrm{Ru}$ умный,

'Allegedly / As it seems, Stefan has left for Burgas.' (Kehayov 2008: 7Не смог удержаться, чтобы не выебнуться, да? Типо какой

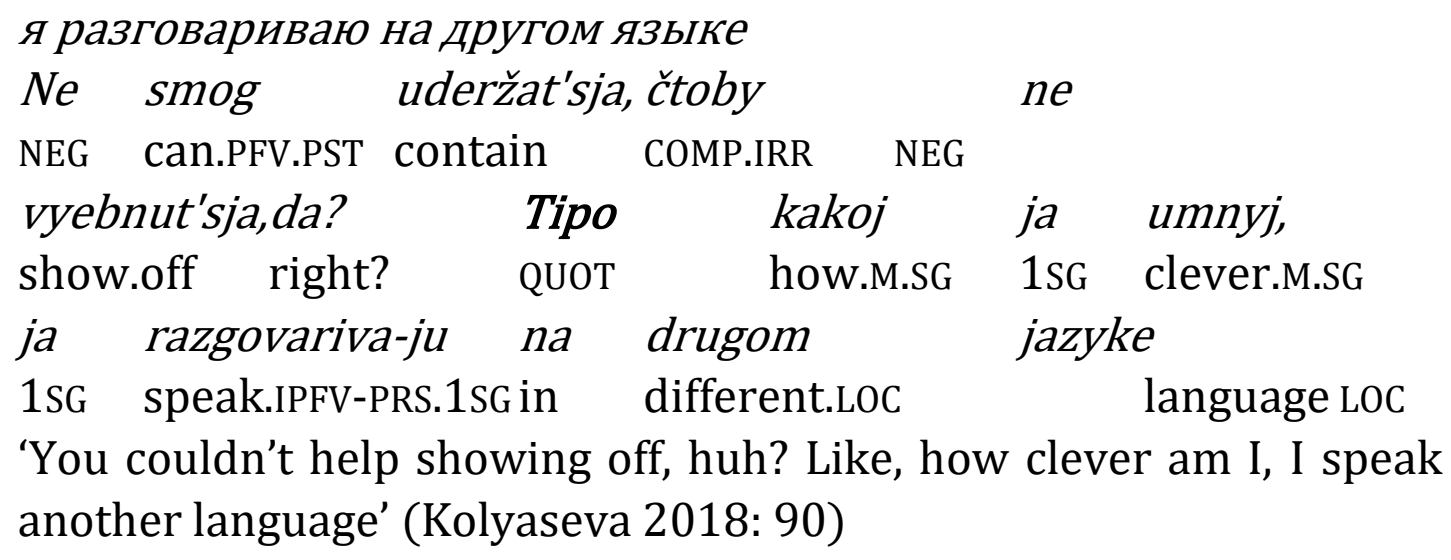

The meaning correspondences between the sentences in (1) may be intuitively clear: all attribute an utterance or thought to some speaker at some moment preceding the current speech event. Yet, they involve a striking variety of forms. The Russian (1) exemplifies a complex sentential strategy, in which the bolded clause describes a speech event and a reported speaker, and the following clause introduces an utterance attributed to this speaker. Sentential strategies of this type are available in all Slavic languages, but the Polish (2) illustrates a different type of speech attribution, using the sentence adverb podobnos 'allegedly'. In the Bulgarian (3), the speech attributing interpretation is merely signalled through the perfect, which in Bulgarian has developed an evidential meaning $(\rightarrow$ Evidentiality). Finally, the Russian (4) illustrates a slightly different type of expression. Like the first three sentences, (4) consists of a sentential element that is attributed to the syntactic subject of the main clause. However, in (4) the referent is unlikely to have actually spoken the words kakoj ja umnyj 'how clever am I?'. Rather, the sentence characterises a description by the current speaker of a potential thought the referent might have had.

For Vološinov (1930), the fact that expressions above show a great variety of form and are often difficult to distinguish from expressions that do not strictly belong to the domain of reported speech is exactly the point. "Reported speech is speech within speech, utterance within utterance, and at the same time also speech about speech, utterance about utterance” (Vološinov 1973: 115). 'Other voices' hide everywhere in and behind our discourse; only reported speech constructions allow us to mark them explicitly, and among these constructions some leave more room for ambiguity. This chapter focuses on expressions of type (1) and (4). Examples (2) and (3) are discussed in the section on reportatives (see also 
$\rightarrow$ Evidentiality). I will refer to (1) as 'quotation' and (4) as 'quotative'. After introducing these two types below, the chapter addresses several open questions from the extensive literature on this topic.

A typology of Slavic quotation and quotatives

Data in this section have been drawn from the Amsterdam Slavic Parallel Aligned Corpus (ASPAC, A. A. Barentsen, p.c.) and ParaSol corpus (Von Waldenfels \& Meyer).

Quotation: Direct and indirect speech

Quotation is a term most directly associated with pragmatics/semantics and roughly covers the opposition between direct and indirect speech constructions. Across European languages, the formal and semantic properties of direct and indirect speech are relatively stable, as illustrated by (5-11). Alice)

a. "I'm sure those are not the right words," said poor Alice (ASPAC-

b. I have said that I saw things which I shall never forget (ASPAC-Lem)

(6) Uk a. Eni, ne ti slova, - promovila bidolašna Alisa [Uk]

b. Ja ž vam uže skazav, ščo pobačiv take, čogo nikoli ne zabudu

(7) $\mathrm{Br}$ a. Ja péŭnaja, što veršyk vyjšaŭ nejki njapravil'ny! - skazala njaščasnaja Alesja

b. Jak ja ŭžo kazaŭ, ja bačyŭ nešta takoe, čaho nikoli ne zabudusja

(8) $\mathrm{Cz}$ a. "Takhle to jistě není," řekla Alenka

b. Řekl jsem vám, že jsem viděl něco, na co nikdy nezapomenu

(9) Po a. Nie, to na pewno nie są właściwe słowa - zasmuciła się Alicja

b. Powiedziałem, że zobaczyłem coś, czego nie zapomnę już nigdy

(10) Mc a. "Sigurna sum deka toa ne se točnite zborovi", si reče kutrata Alisa

b. Rekov deka vidov nešto što nikogaš nema da go zaboravam

(11) Sl a. "Stavim, da to niso prave besede," si je rekla uboga Alica

b. Povedal sem, da sem videl nekaj, iesar ne bom nikoli vei pozabil

All a-sentences in (5-11) represent direct speech. The bolded elements, which I will refer to as the matrix clause, describe a speech event in which the grammatical subject is the primary agent, the 'reported speaker'. Matrix clauses typically contain verbs of speech, but this is not necessarily the case, as the Polish translation in (9a) illustrates: here, the verb zasmucić się 'become sad, grieve' is used to reflect a manner of speech. 
The non-bolded clauses in (5-11), which I will refer to as 'quote', represent a locution attributed to the reported speaker. A quote may consist of any expression type, from a single interjection or (verbal) gesture to a stretch of discourse (Güldemann 2008: 275-277). In (5-11), all matrix clauses take a sentence final position but, like in English, may also occur in initial position or interpolate the reported message. While this flexibility suggests that matrix clauses are relatively autonomous syntactic units, matrix clauses in all Slavic languages are ungrammatical without the presence of a quote.

The b-sentences in (5-11), except the Belarusian example (7b), illustrate indirect speech. Syntactically, indirect speech mostly corresponds to a complement clause construction with a main clause, typically containing a verb of speech and a clause headed by a complementizer (but see below).

Traditionally, the distinction between direct and indirect speech has mostly been characterised in terms of the deictic elements involved $(\rightarrow$ Deixis). In direct speech, deictic words in the quote refer as in the reported speech event, i.e. in (5a11a) the words 'I' and 'those' refer to a context in which Alice allegedly spoke these words. Deictics in matrix clauses of direct speech and all deictics in indirect speech refer as in the current speech event. For formal semantics, the referential properties of direct speech present an interesting anomaly since it disrupts the idea that deictic elements can be given a truth value with respect to the current discourse context $(\rightarrow$ Formal semantics). This also implies a rather strict division between indirect speech, which can be treated as representatives of a class of attitude ascriptions more generally and quotation proper (Maier 2019).

In Slavic and functionalist linguistics, most interest has been raised by the opposition between direct and indirect speech. Semantically, direct speech constructions suggest that the quote accurately reflects the words of the reported speaker (in rhetorical terms, the quote is reported de dicto). In Wierzbicka's (1974: 273) characterisation, the speaker signals: 'I imagine that I am him saying this', acting as if the current speaker speaks the words of the reported speaker. With indirect speech constructions, on the other hand, 'one undertakes to state the content of the speech as though one were prepared to assert it oneself (Wierzbicka 1974: 284-285). This meaning is more ambiguous: a direct speech construction can still be taken to mean that the current speaker intends to convey the words of the reported speaker. For example, in (5b-11b) the speaker may well have said "I saw things which I shall never forget" in the reported speech event. But an indirect speech construction can also be taken as a reformulation of the alleged utterance by the reported speaker. In rhetorical terms, indirect speech allows both for a de dicto and a de re interpretation. 
One reason why indirect speech in Slavic cannot be strictly separated from quotation based on its deictic properties is that tense features in the quote do not 'adjust' to the current speech situation. Indirect speech constructions in Slavic do not display, so called, 'sequence of the tenses' (Evans 2013: 79-80). Specifically, whereas in many other European languages tense in a quote is often adjusted to the value of the tense of the main clause in indirect speech, as in the English translation of (9), in all Slavic languages the tense of the main verb usually has the same value both in direct speech and in indirect speech.

(12) $\mathrm{Ru}$

Ivan skaza-l, čto on priede-t

Ivan say.IPFV-PST CMPL 3M.SG arrive.PFV-3M.SG

'Ivan said that he would (lit.: will) arrive' (Barentsen 1996: 16)

Within the Russian grammar tradition, the behaviour of tense in quotes classifies their accompanying main clauses as изъяснительные придаточные предложения iz"jasnitel'nye pridatočnye predloženija 'explanatory dependent clauses' (Barentsen 1996: 18-19). In addition to speech verbs, members of this construction class include cognitive verbs (e.g. Ru dumat' 'think', znat' 'know'), verbs related to perception (e.g. Ru videt"see', pokazat'sja 'seem') and attitudinal predicates (e.g. Ru xotet' 'want', byt' dosadno '(be) annoy(ed by)'). As Barentsen (1996) meticulously demonstrates for Russian, however, tense choice in the clause following such main clauses can vary. With matrix predicates related to perception of a past event, as in (13-14), tense homogeny as in (14), where both verbs in the matrix and embedded clause share the same past tense form, results in a factual reading: the speaker states that the event described in the embedded clause has actually occurred. If the tense value of the embedded tense verb is not adjusted to that of the matrix verb, as in (13) the event 'exists only in the mind of the person we are talking about' (Barentsen 1996: 21).

(13) $\mathrm{Ru}$

Иван видел что она придет

Ivan vide-l, čto ona pride-t

Ivan see.IPFV-PST CMPL 3F.SG arrive.PFV-3SG

'Ivan saw that she had arrived' [Describes Ivan's internal state]

(14) $\mathrm{Ru} \quad$ Иван видел, что она пришла

Ivan vide-l, čto ona priš-l-a

Ivan see.IPFV-PST CMPL 3F.SG arrive. IPFV-PST-3F.SG

'Ivan saw that she had arrived' [Speaker states the fact that she has arrived]

The tense patterns in Slavic indirect speech can be semantically explicated by their connection to explanatory clauses: the tense 'shift' grounds the quote in the 
mind of the reported speaker. Slavic indirect speech clearly signals that the speaker does not state the content of the quote as fact, but as a subjective reality. In Vološinov's (1930) analysis, the structural properties of direct and indirect speech transparently reflect the way in which speakers can talk about each other's words. The strict separation between the matrix clause and the quote in terms of deictic properties and lack of markers of inter-clausal dependency signals that the speaker portrays the voice of the reported speaker as an 'autonomous' element within the utterance. The closer integration of matrix clause and quote in indirect speech indicates a mixing of voices between that of current speaker and the reported speaker.

\section{Quotatives}

Güldemann (2008) coins the term 'quotative index' to refer to matrix clauses such as those in the direct speech constructions (2a-8a). This step opens up two new analytical options: first, it allows us to qualify a clausal element as a functional unit signalling quotation; and second, it allows us to compare matrix clauses to non-clausal elements that perform a similar function in combination with quotes. Buchstaller \& Ingrid Van Alphen (2012) adopt the term 'quotative' in this broad sense to cover both more traditional 'introducers' of quotation and 'new quotatives', a term originally stemming from (English) sociolinguistics.

Typical examples of 'new quotatives' in the literature include such expressions as 'I went "hey"!' and 'She was like "Oh, no".' As Buchstaller \& Ingrid van Alphen (2012) demonstrate, 'new quotatives' are neither very new nor restricted to English, and most contributors to Buchstaller \& Ingrid Van Alphen (2012) use the term 'quotative' as a shorthand for a variety of non-clausal and clausal introducers of quotation. Holvoet (2018) credits the volume with coining the term in this sense (also $\rightarrow$ Echoic deontics) and cites a Russian example as in (11).

$\begin{array}{lll}\text { Ne } & \text { puskajut } i & \text { posmatrivajut na } \\ \text { NEG } & \text { let.in.PRS.3.PL } & \text { and cast.looks.PRS.3.PL at } \\ \text { nas: } & \text { nu kak, mol? } \\ \text { 1PL.ACC } \quad \text { well how } & \text { QUOT }\end{array}$

'They won't let us in and cast looks at us [as if they wanted to say] well, what now?' (Holvoet 2018: 247)

Compared to the direct and indirect speech examples above, one aspect of (15) stands out: there is no actual speech attribution in the example, as reflected by the translation 'as if they wanted to say'. In (15) the speaker approximates 
something the grammatical subject might have said. This points to a defining feature of quotatives Romaine \& Lange (1991: 228) observe in their description of American English be like-constructions: "When like is used in a quotative function, it allows the speaker to retain the vividness of direct speech and thought while preserving the pragmatic force of indirect speech". In other words, a quotative expression enacts the quote, but is also understood as being explicitly voiced by the current speaker. It presents itself as a de re version of direct speech.

Even though (new) quotatives have been most extensively described for English, the phenomenon has received considerable attention in Slavic as well, particularly in Russian linguistics. Here, most interest has been raised by the Russian particles mol (as in 15), deskat' and -de, derived from the old speech verb molviti 'speak', skazati 'say' and dejati 'talk, say', respectively (Arutjunova 2000: 437).

Arutjunova (2000: 438-442) refers to these particles as ksenopokazateli, dubbed into English as 'xenomarkers' (Levontina 2011). She notes that mol, deskat'and $d e$ are extraordinarily versatile in their syntactic placement and often combine with features of direct speech, but may appear in indirect speech as well. An example of the latter is (16).

(16) Ru On probormotal čto-to vrode: "Razum i džungli", na čto Robert

pariroval, čto, deskat', razum tože dik

'He mumbled something like 'Intellect versus savagery,' to which Robert replied

that intellect itself was savage too' (ASPAC-DeMoor)

The xenomarker deskat' in (16) signals that the proposition razum tože dik 'the intellect is savage too' is an approximation of the intention of Robert's riposte. It is "authored" (Goffman 1979) by the current speaker as a general characterisation of Robert's alleged speech act. This is exactly the function of a quotative: it allows the speaker to represent a communicative action, an intention, an attitude rather than convey an exact form or substance of a quote (Arutjunova 2000: 444). Sonnenhauser (2010) suggests that this property also distinguishes utterances marked with $\mathrm{mol}$ and deskat' from reported speech in the sense of Vološinov (1930): quotatives are only speech about speech, not speech within speech (see Vološinov's (1930) definition above).

Arutjunova (2000: 441) states that unlike the English quotatives, the xenomarkers above are uncommon in (contemporary) spoken discourse (but see Plungjan (2008) for a contrasting, corpus-based view). A quotative particle that does carry this function in modern spoken Russian is tipa/ tipo (as in 1d) (Daiber 
2010; Kolyaseva 2018; Sergeeva 2010; Spronck 2016). As Kolyaseva (2018: 83) writes, this particle appears to take over many of the functions of the older xenomarkers, but also has additional rhetorical uses that lie outside the domain of quotation (Kolyaseva 2018: 93).

Outside of Russian, quotatives are increasingly being studied as well (see e.g. Wiemer \& Kampf 2013). Quotative particle constructions are found throughout the Slavic languages. For example, Serbian, Bosnian and Montenegrin have the particle tobože 'as if' (Wiemer \& Vrdoljak 2011; Wiemer 2018; Max Wahlström, p.c.). Macedonian has the cognate adjective tobožnji 'so-called', and uses the Turkish loan demek 'as if' in a quotative function (Miteva-Markovikj 2018: 58). Buchstaller \& Ingrid van Alphen (2012: iv) list the Czech quotative particles jako ( $\check{e}$ ) 'as' and na to '(uttered/argued) against this' (lit. 'on this'), Po typu '< type' and $\dot{z} e$ as well as Cr kao'as if'.

Each of the examples introduced above comply with the diachronic observation that common sources for quotative markers are speech verbs, comparative/simulative elements and demonstratives (Buchstaller \& Ingrid van Alphen 2012: xiv; Güldemann 2008). Guz (2019a) lists a wide array of direct speech and quotative strategies in Polish, including the demonstrative construction in (17) and the quotative marker/ complementiser $\dot{z} e$ (18).

(17) Po ja taka 'okej'

I was like this "Okay" (Guz 2019a: 209)

(18) Po to one były że 'nie że o ja że na Riri to się zawsze czeka' 'they were ŻE "no, ŻE oh my, ŻE you always wait for Riri”' (Guz 2019a:

Interestingly, while $\dot{z} e$ acts as a complementiser elsewhere, in (18) it appears to mark quotativity by itself (also see Guz 2018). Guz (2019b) argues that the two uses of $z e$ have followed distinct grammaticalisation paths and that in contemporary Polish the quotative marker $\dot{z} e$ and the complementiser $\dot{z} e$ are in complementary distribution.

\section{Complications}

Quotation as a prescriptive ideal, and a reality in use

Much research into quotation has been driven by the observation that the distinction between direct and indirect speech is considerably less binary than once assumed. Prescriptive conventions about the use of deictics, tense and mood 
in indirect speech, for example, are frequently violated across languages (Bolkestein 1976; Davidse \& Vandelanotte 2011; Maier 2017). In spoken language, not marking quotation at all, a strategy dubbed 'zero quotative' (Mathis \& Yule 1994), is common (also cf. Spronck 2017; Si \& Spronck 2019; Gentens et al. 2019). And in a study of spontaneous Russian conversation Bolden (2004) finds that even though the language has a range of morpho-syntactic, prosodic and performative strategies for marking the boundaries of a quote in direct speech, speakers may choose not to use them.

The approach to reported speech sketched by Vološinov (1930) anticipates this observation. Vološinov's (1930) idea that reported speech involves the mixing of voices of multiple types is epitomised in the phenomenon of 'free (in)direct speech' (Bally 1912; Kurt 1999; Lips 1926; Socka 2004; Tomasik 1992; Vološinov 1930). This phenomenon takes many different forms, but can to some degree be defined as expressions of direct or indirect speech that receive no or atypical marking.

The difficulties of drawing the boundaries of quotation may be illustrated with (19-23). In the Czech original in (19) (taken from Milan Kundera's The Unbearable Lightness of Being) the bolded sentence is headed by the particle prý 'allegedly', from praví '3sg.prs:say', marking hearsay (Hoffmannová 2008; Wiemer \& Kampf 2013: 155). In the Russian translation (21) it is rendered as indirect speech. The Polish translation (22) involves the sentence adverb podobno 'allegedly' and the Bulgarian version (23) includes the narrative/evidential perfect (Kehayov 2008; Makarcev 2008), i.e. 'apparently, she had cancer'.

(19) $\mathrm{Cz}$ Jednou jí matka telefonovala. Prý má rakovinu (ParaSolkunderalehkost)

(20) En One day her mother phoned to say she had cancer

(21) $\mathrm{Ru}$ Odnaždy mat' pozvonila ej. Skazala, čto u nee rak

(22) Po Pewnego razu matka zatelefonowała. Podobno ma raka

(23) Bg Edin den majka i telefonira. Imala rak

In one of the earliest theoretical discussions of evidentiality in Slavic, Jakobson (1957) identifies the Bulgarian narrative past participle form in (23) as an example of morphologically expressed evidentiality and equates it to quotative particles de, $\mathrm{mol}$ and direct/indirect speech in Russian. This has view has been contested in subsequent research on evidentiality $(\rightarrow$ Evidentiality). But the relevant observation about these examples is that the bold sentences, while of different types, can be unambiguously interpreted as a reported utterance given 
the context of the immediately preceding clause. This illustrates the contextdependency of many of these expressions, which complicates the task of determining whether an expression of reflecting other people's words counts as a quotation in a strict sense (consider also $\rightarrow$ Jako recitativum).

Another interesting example of this observation is the Belarusian translation in (7b), which, apart from the phrase Jak ja ŭžo kazaŭ... 'As I already said...' does not include any marking of quotation. This brings up the question how this phrase relates to, e.g., the sentence adverbs found in (19) and (22) (do they all have a similar function with respect to the clause under their scope?), and whether the functions of quotation actually can be adequately captured in syntax. Authors differ in the syntactic analysis of such sentences, and the elements that can be recognised as markers of quotation.

Syntactic analyses of quotation also differ in the view of whether, e.g. the matrix clause or quotative particle primarily marks quotation/quotativity (e.g. Güldemann 2008), or whether it is the relation between the matrix clause and the quote that is relevant (e.g. McGregor 1997, Spronck \& Nikitina 2019). Authors working in a conversation analytical or sociolinguistic paradigm, such as Bolden (2004), would argue that these constructions should not primarily be discussed in terms of syntax at all, but rather as a complex of multimodal signals (e.g. D'Arcy 2015).

A final aspect of the research programme Vološinov (1930) sets out is to examine the interaction between literary, written genres and reported speech expressions. In this connection it is interesting to note that while spoken language typically prefers types of direct speech (Bolden 2004: 1080), written language shows a preference for more complex and diverse strategies as early as in Old Russian (pre-1500), as Collins (2001) concludes on the basis of trial transcripts. In a corpus study of Old Russian birch bark writings Dekker (2018: 92) finds that the proportion of direct speech significantly declines over the examined period 11001430. These observations suggest that quotation is not only highly variable, its manifestation is genre dependent and influenced by different modes of communication.

\section{The status of 'demonstration' as a semantic value}

In the literature on quotation and reported speech the category of evidentiality (cf. Jakobson 1957; but $\rightarrow$ Evidentiality), and modal notions such as 'distancing' (cf. Güldemann 2008) have figured prominently. But there is a third semantic 
notion that has been central to the description of quotation: 'demonstration'. Clark \& Gerrig (1990) introduce this notion to capture a property of quotation that had also long preoccupied formal semanticists: a quote does not describe, i.e. it does not simply represent a proposition. Instead, Clark \& Gerrig (1990) propose, it serves to demonstrate or, in a more recent formulation (Clark 2016), 'depict' its content. This view partly corresponds to what has come to be known as the 'demonstrative theory' of quotation in formal semantics (Saka 2006): the idea that a quote 'points' or merely 'shows' an utterance or proposition. A similar analysis has also been formulated in terms of a quote being 'iconic' rather than 'symbolic' (De Brabanter 2017; Recanati 2001).

For Clark \& Gerrig (1990) this property only applies to direct speech, but given that the boundaries between direct and indirect speech are often blurred, later authors have used it in a broader sense (McGregor 1997). And indeed, Clark (2016) applies the notion demonstration/depiction to reported speech more generally (Clark 2016: 331). Authors differ in whether this value is ultimately a qualification of communicative action (Ferrara \& Hodge 2018), a pragmatic notion (De Brabanter 2017) or a necessary conventional property of a construction of quotation (Spronck \& Nikitina 2019).

\section{Fictive interaction}

Quotative expressions often reflect 'non-actual' locutions. Buchstaller (2014: 8) even notes that the English 'new quotative' be like was used to express internal states and thought before signalling speech. And Güldemann (2008) finds that quotative indexes in African languages display a wide range of functions beyond speech.

It should be noted that this function is by no means reserved for quotatives. Compare example (24).

(24) En Winston had woken up with his eyes full of tears. Julia rolled sleepily against

him, murmuring something that might have been 'What's the matter?' (ASPAC

Orwell)

(25) Uk Vinston prokinuvsja z očima povnimi sliz. Džulija prigornulasja do n'oho sprosonnja, probubonivši ščos' ščo mohlo označati "Ščo stalosja?".

Only the Ukrainian translation of (24) is shown in (25), but in the ParaSolsample all examples express the sentence as a type of direct speech. Direct 
speech forms in particular are frequently used to express non-actual speech events, or to attribute speech to non-actual speakers in the languages of the world (Pascual 2014: ch, 4). Pascual (2014) labels such expressions (e.g. 'A facial expression that says: "Come here"') as part of a broader phenomenon, which she calls 'fictive interaction'.

Keywords: Quotation, quotatives, direct speech, reported speech, free indirect speech, fictive interaction

\section{References}

Arutjunova, H. D. 2000. Pokazateli cužoj reci ẹ, deskat', mol. K probleme interpretacii recepovediceskix aktov. In H. D. Arutjunova (ed.), Jazyk o jazyke, 437-449. Moskva: Jazyki russkoj kul'tury.

Bally, Charles. 1912. Le style indirect libre en français moderne I \& II. Germanisch-Romanische Monatschrift 4. 549-556, 598-606.

Barentsen, Adrian. 1996. Shifting points of orientation in Modern Russian: Tense selection in 'reported perception. In Theo Janssen \& Wim van der Wurff (eds.), Reported Speech: Forms and functions of the verb, 15-55. Amsterdam/Philadelphia: John Benjamins.

Bolden, Galina. 2004. The quote and beyond: defining boundaries of reported speech in conversational Russian. Journal of Pragmatics 36(6). 1071-1118. doi:10.1016/j.pragma.2003.10.015.

Bolkestein, A. Machtelt. 1976. The relation between form and meaning of Latin subordinate clauses governed by verba dicendi. Mnemosyne 29(2). 155-175.

Brabanter, Philippe De. 2017. Why quotation is not a semantic phenomenon, and why it calls for a pragmatic theory. In Ilse Depraetere \& Raf Salkie (eds.), Semantics and Pragmatics: Drawing a Line, 227-254. Dordrecht etc.: Springer.

Buchstaller, Isabelle. 2014. Quotatives: New Trends and Sociolinguistic Implications. Oxford etc.: Wiley-Blackwell.

Buchstaller, Isabelle \& Ingrid Van Alphen (eds.). 2012. Quotatives: Cross-linguistic and crossdisciplinary perspectives. Amsterdam/Philadelphia: John Benjamins.

Buchstaller, Isabelle \& Ingrid van Alphen. 2012. Preface: Introductory remarks on new and old quotatives. In Isabelle Buchstaller \& Ingrid van Alphen (eds.), Quotatives: Cross-linguistic and cross-disciplinary perspectives, xi-xxx. Amsterdam/Philadelphia: John Benjamins.

Clark, Herbert H. 2016. Depicting as a method of communication. Psychological Review 123(3). Clark, Herbert H.: Stanford University, Jordan Hall, Building 420, Stanford, CA, US, 94305-2130, clark@stanford.edu: American Psychological Association. 324-347. doi:10.1037/rev0000026.

Clark, Herbert H. \& Richard J. Gerrig. 1990. Quotations as demonstrations. Language 66. 764-805.

Collins, Daniel E. 2001. Reanimated Voices, Speech reporting in a historical-pragmatic perspective (Pragmatics\&BeyondNewSeries). . Vol. 85. Amsterdam/Philadelphia: John Benjamins.

D’Arcy, Alexandra. 2015. Quotation and Advances in Understanding Syntactic Systems. Annual Review of Linguistics 1(1). 43-61. doi:10.1146/annurev-linguist-030514-125220.

http://dx.doi.org/10.1146/annurev-linguist-030514-125220.

Daiber, Thomas. 2010. Quotativmarker im Russischen. Zeitschrift für Slawistik55(1). 69-89.

Davidse, Kristin \& Lieven Vandelanotte. 2011. Tense use in direct and indirect speech in English. Journal of Pragmatics 43. 236-250.

Dekker, Simeon. 2018. Old Russian Birchbark Letters: A Pragmatic Approach. Leiden: Brill/Rodopi.

Evans, Nicholas. 2013. Some problems in the typology of quotation: a canonical approach. In Dunstan Brown, Marina Chumakina \& Greville G. Corbett (eds.), Canonical Morphology and Syntax, 6698. Oxford etc.: Oxford University Press. 
Ferrara, Lindsay \& Gabrielle Hodge. 2018. Language as Description, Indication, and Depiction. Frontiers in Psychology 9. doi:10.3389/fpsyg.2018.00716.

Gentens, Caroline, Maria Sol Sansiñena, Stef Spronck \& Van linden An. 2019. Introduction to Irregular Perspective Shifts and Perspective Persistence, Discourse-Oriented and Theoretical Approaches. Pragmatics. Amsterdam/Philadelphia: John Benjamins.

Goffman, Erving. 1979. Footing. Semiotica 25(1-2). 1-30.

Güldemann, Tom. 2008. Quotative Indexes in African Languages: A synchronic and Diachronic Survey. Berlin: Mouton de Gruyter.

Guz, Wojciech. 2018. Quotative uses of Polish że in direct speech reports. In Wojciech Guz \& Bogdan Szymanek (eds.), Canonical and non-canonical structures in Polish, 71-96. Lublin: Wydawnictwo KUL.

Guz, Wojciech. 2019a. Direct quotation strategies in conversational Polish. In Anna Bondaruk \& Krzysztof Jaskuła (eds.), All around the word: Papers in honour of Bogdan Szymanek on his 65th birthday, 193-222. Lublin: Wydawnictwo KUL.

Guz, Wojciech. 2019b. Quotative uses of Polish że in direct speech reports. Lublin: Wydawnictwo KUL.

Hoffmannová, Jana. 2008. Role ceského prý/prej/pré pri vyjadrování reproduktivních a modálních význam. In Vladimir Plungian \& Björn Wiemer (eds.), Lexikalische Evidenzialitäts-Marker in slavischen Sprachen, 149-164. München/Vienna: Otto Sagner.

Holvoet, Axel. 2018. Epistemic modality, evidentiality, quotativity and echoic use. In Zlatka Guentchéva (ed.), Epistemic Modality and Evidentiality in a Cross-Linguistic Perspective. Berlin/New York:

Jakobson, Roman. 1957. Shifters, verbal categories and the Russian verb. Department of Slavic Languages and Literatures, Cambridge, MA: Harvard University.

Kehayov, Petar. 2008. Interactions between grammatical evidentials and lexical markers of epistemicity and evidentiality: a case study of Bulgarian and Estonian. In Vladimir Plungian \& Björn Wiemer (eds.), Lexikalische Evidenzialitäts-Marker in slavischen Sprachen, 165-201. München/Vienna: Otto Sagner.

Kolyaseva, Alena F. 2018. The "new" Russian quotative tipa: Pragmatic scope and functions. Journal of Pragmatics 128. 82-97. doi:https://doi.org/10.1016/j.pragma.2018.03.004. https://www.sciencedirect.com/science/article/pii/S0378216617303314.

Kurt, Sibylle. 1999. Erlebte Rede aus linguistischer Sicht: Der Ausdruck von Temporalität im Französischen und Russischen. Bern etc.: Peter Lang.

Levontina, Irina. 2011. Xenomarkers in Russian.

Lips, Marguerite. 1926. Le style indirect libre. Paris: Payot.

Maier, Emar. 2017. The Pragmatics of Attraction: Explaining Unquotation in Direct and Free Indirect Discourse. In P. Saka \& M. Johnson (eds.), The Semantics and Pragmatics of Quotation, 259280.

Maier, Emar. 2019. On the exceptionality of reported speech. Linguistic Typology.

Makarcev, Maksim M. 2008. K voprosu o svjazi leksičeskix i grammatičeskix pokazatelej èvidencial'nosti v bolgarskom jazyke. In Vladimir Plungian \& Björn Wiemer (eds.), Lexikalische Evidenzialitäts-Marker in slavischen Sprachen, 239-284. München/Vienna: Otto Sagner.

Mathis, Terrie \& George Yule. 1994. Zero quotatives. Discourse Processes 18(1). 63-76. doi:10.1080/01638539409544884. http://dx.doi.org/10.1080/01638539409544884.

McGregor, William B. 1997. Semiotic Grammar. Oxford: Clarendon Press.

Miteva-Markovikj, Keti. 2018. About the Stylistic Adaptation of Turkish Loanwords in Macedonian. European Scientific Journal 14(20).

Pascual, Esther. 2014. Fictive Interaction: The Conversation Frame in Thought, Language, and Discourse. Amsterdam/Philadelphia: John Benjamins.

Plungjan, Vladimir A. 2008. Ob pokazatel'jax čužoj reči i nedostovernosti v russkom jazyke: mol, jakoby i drugie. In Björn Wiemer (ed.), Lexikalische Evidenzialitätsmarker im Slavischen, vol. Sonderband 72, 285-311. Wien: Wiener Slawistischer Almanach.

Recanati, François. 2001. Open Quotation. Mind 110(439). 637-687.

Romaine, Suzanne \& Deborah Lange. 1991. The Use of like as a Marker of Reported Speech and Thought: A Case of Grammaticalization in Progress. American Speech 66(3). 227-279. 
Saka, Paul. 2006. The Demonstrative and Identity Theories of Quotation. The Journal of Philosophy 103(9). 452-471.

Sergeeva, E. N. 2010. Tipa kak èvidential'nyj marker v russkoj razgovornoj reci. In N. N. Kazanskij (ed.), Acta Linguistica Petropolitana: Trudy instituta lingvisticeskix issledovanij, vol. IV, 149-153.

Si, Aung \& Stef Spronck. 2019. Solega defenestration: Underspecified perspective shift in an unwritten Dravidian language. Pragmatics. Quarterly Publication of the International Pragmatics Association (IPrA) 29(2). John Benjamins Publishing Company. 277-301. doi:10.1075/prag.18048.si.

Socka, Anna. 2004. Sprachliche Merkmale der erlebten Rede im Deutschen und Polnischen. Berlin/Boston: Walter de Gruyter.

Sonnenhauser, Barbara. 2010. Rededarstellung im Russischen: "mol" und "deskat. Zeitschrift für Slavische Philologie 67(2). 377-405. http://www.jstor.org/stable/24004159.

Spronck, Stef. 2016. Evidential fictive interaction (in Ungarinyin and Russian). In Esther Pascual \& Sergeiy Sandler (eds.), The Conversation Frame: Forms and Functions of Fictive Interaction, 255-275. Amsterdam/Philadelphia: John Benjamins.

Spronck, Stef. 2017. Defenestration: deconstructing the frame-in relation in Ungarinyin. Journal of Pragmatics 114. 104-133. doi:https://doi.org/10.1016/j.pragma.2017.03.016. http://www.sciencedirect.com/science/article/pii/S0378216616304398.

Spronck, Stef \& Tatiana Nikitina. 2019. Reported speech constructions are a dedicated syntactic domain: Typological arguments and observations. Linguistic Typology 23(1).

Tomasik, Wojciech. 1992. Od Bally'ego do Banfield (I daloej). Sześć rozpraw o „mowie pozornie zależnej. Bydgoszcz.

Vološinov, Valentin N. 1930. Marksizm i filosofija jazyka. 2nd ed. Leningrad: Priboj.

Vološinov, Valentin N. 1973. Marxism and the Philosophy of Language. (Ed.) Ladislav Matejka \& I.R. Titunik. New York/London: Seminar Press.

Waldenfels, Ruprecht Von \& Roland Meyer. ParaSol, a Parallel Corpus of Slavic and Other Languages. Bern, Regensburg. parasol.unibe.ch, www-korpus.uni-r.de/ParaSol.

Wiemer, Björn. 2005. Conceptual affinities and diachronic relationships between epistemic, inferential and quotative functions (preliminary observations on lexical markers in Russian, Polish and Lithuanian). In Björn Hansen \& Petr Karlík (eds.), Modality in Slavonic Languages. New Perspectives, 107-131. München: Otto Sagner.

Wiemer, Björn. 2018. Catching the Elusive: Lexical evidentiality markers in Slavic languages (A questionnaire study and its background). Berlin: Peter Lang.

Wiemer, Björn \& Veronika Kampf. 2013. Gesten und Mimik als semiotische Substitute für Sprechakte oder umgekehrt? Zur speziellen Verwendung einiger Reformulierungsmarker im Bulgarischen. Contrastive Linguistics XXXVIII(2-3). 153-191.

Wiemer, Björn \& Ivana Vrdoljak. 2011. Evidenzielle Partikeln Vs. Satzadverbien im Serbischkroatischen und Slovenischen. Teil I. Ein Forschungsbericht. Die Welt der Slaven LVI. 100-130.

Wierzbicka, Anna. 1974. The Function of Direct and Indirect Discourse. Papers in Linguistics 7(3). 267-307. 